\title{
Toward a Social-Ecological Theory of Forest Macrosystems for Improved Ecosystem Management
}

\author{
William J. Kleindl ${ }^{1, *}$, Paul C. Stoy ${ }^{1}$, Michael W. Binford ${ }^{2}{ }^{(1)}$, Ankur R. Desai ${ }^{3}{ }^{(1)}$, \\ Michael C. Dietze ${ }^{4}(\mathbb{D})$, Courtney A. Schultz ${ }^{5}$, Gregory Starr ${ }^{6}{ }^{(1)}$, Christina L. Staudhammer ${ }^{6}$ and \\ David J. A. Wood 1,7 (iD) \\ 1 Department of Land Resources and Environmental Sciences, Montana State University, 334 Leon Johnson \\ Hall, Bozeman, MT 59717, USA; paul.stoy@montana.edu (P.C.S.); dwood@usgs.gov (D.J.A.W.) \\ 2 Department of Geography, University of Florida, Gainesville, FL 32611, USA; mbinford@ufl.edu \\ 3 Department of Atmospheric and Ocean Sciences, University of Wisconsin, 1225 W Dayton St, Madison, \\ WI 53706, USA; desai@aos.wisc.edu \\ 4 Department of Earth and Environment, Boston University, 685 Commonwealth Ave Rm 130, Boston, \\ MA 02215, USA; dietze@bu.edu \\ 5 Department of Forest and Rangeland Stewardship, Colorado State University, 1472 Campus Delivery, \\ Fort Collins, CO 80523, USA; courtney.Schultz@colostate.edu \\ 6 Department of Biological Sciences, University of Alabama, PO Box 870344, Tuscaloosa, AL 35487, USA; \\ gstarr@ua.edu (G.S.); cstaudhammer@ua.edu (C.L.S.) \\ 7 U.S. Geological Survey Northern Rocky Mountain Science Center, 2327 University Ave., Ste. 2, Bozeman, \\ MT 59715, USA \\ * Correspondence: william.kleindl@montana.edu; Tel.: +1-406-599-7721
}

Received: 6 March 2018; Accepted: 2 April 2018; Published: 11 April 2018

\begin{abstract}
The implications of cumulative land-use decisions and shifting climate on forests, require us to integrate our understanding of ecosystems, markets, policy, and resource management into a social-ecological system. Humans play a central role in macrosystem dynamics, which complicates ecological theories that do not explicitly include human interactions. These dynamics also impact ecological services and related markets, which challenges economic theory. Here, we use two forest macroscale management initiatives to develop a theoretical understanding of how management interacts with ecological functions and services at these scales and how the multiple large-scale management goals work either in consort or conflict with other forest functions and services. We suggest that calling upon theories developed for organismal ecology, ecosystem ecology, and ecological economics adds to our understanding of social-ecological macrosystems. To initiate progress, we propose future research questions to add rigor to macrosystem-scale studies: (1) What are the ecosystem functions that operate at macroscales, their necessary structural components, and how do we observe them? (2) How do systems at one scale respond if altered at another scale? (3) How do we both effectively measure these components and interactions, and communicate that information in a meaningful manner for policy and management across different scales?
\end{abstract}

Keywords: macrosystem; macroscale; forest; management; ecosystem function; ecosystem service; cross-scale; trade-off; governance; social-ecological system

\section{Introduction}

Society is now more aware of the effects of cumulative land-use decisions on ecological systems across scales. Developments in remote sensing technology, monitoring networks, and Earth system models [1] have enabled us to observe the coupled effects of land management and climate change [2,3] that are perturbing current disturbance regimes, resulting in changes in phenology, altered species 
distributions, species extinctions, and ecological simplification [4-6]. As our awareness of large-scale environmental problems increases, so does our concern about how to manage the environment at the multiple scales at which they are impacted [7]. For example, we have developed great expertise to plan and manage forests strategically at local to regional scales-on the order of meters to hundreds of kilometers-in an attempt to sustain a suite of ecosystem processes necessary to balance the multiple ecological services they provide [8-11]. However, as we begin to consider how cumulative planning and management actions affect forests at regional to continental scales, on the order of hundreds to thousands of kilometers, it is unclear if existing theory will translate to effective management at these broader scales [12-14].

Planning and management approaches (which we will simply call "management") at ecosystem and landscape scales attempt to reconcile multijurisdictional and multiple objective challenges through a participatory process among science, policy, resource managers, and the public, e.g., [15-18]. Even organizations within the United States with jurisdictions at large scales still primarily set objectives, implement specific management, and assess the results of actions at the local field office (BLM), national forest (USFS), park (NPS) or state Forest Action Plans. However, in light of ecosystem responses to global changes, we are now aware that larger scale (i.e., "macroscale") forest management may be necessary for effective management of the overall Earth system [13,19]. Following Heffernan and others [13], we define forest macrosystems as regional to continental areas made up of biotic, abiotic, and human components that interact with one another and with phenomena at other spatial and temporal scales. As this is a burgeoning field in ecology and Earth system science, the challenge will be to communicate these complexities to facilitate an effective participatory process for forest management problems that exist at these large scales.

Macrosystems cross ownership and jurisdictional boundaries, and are subject to cumulative management decisions that are coupled with other large-scale global perturbations. Cumulative land-use decisions and global change must be taken into consideration if management is to be effective at these much larger scales. Despite the growing need to establish management strategies at macroscales, e.g., [20-22], our understanding of macroecological ecosystem structure and function is still at an early stage, as is our understanding of how individual components operate in the context of the social-ecological systems that encompass them [13].

Ongoing and often slow progress in social-ecological understanding reflects a long, iterative, and sometimes contentious relationship between: (1) ecological theory, which helps in understanding the structure and function of ecosystems; (2) public opinion and governance institutions, which determines which ecological goods and services are valued and how they are managed; and (3) resource management, which attempts to maintain ecosystems and their benefits [23-25]. Through these relationships, we define management goals at the stand and landscape scales (e.g., U.S. National Forest boundaries) [26,27], and create strategies to manage adaptively for emerging and novel ecosystem characteristics under global change [26,28].

We argue that to facilitate the definition of management goals at macroscales, the ecological community must provide three important components: (1) ecological assessment tools that, through an easily-understood interpretation of ecological data, can be used to integrate science into decision efforts in ways that facilitate management and public support [23,29]; (2) effective theories for macroecological systems that allow for the development of productive abstract analysis and hypothesis testing; and (3) a framework for testing these theories empirically using the growing body of monitoring data and modeling efforts.

This article explores the current theoretical, empirical, and practical constructs of a social-ecological system as applied to forests, and then discusses pathways to apply these constructs at the scale of forest macrosystems. We use examples of two forest initiative efforts that operate at a macroecological scale and discuss how these efforts provide a framework for assessment approaches that interface between social and ecological aspects of macrosystems. From such a framework, we apply ecological 
theories to address how these management schemes shape forest processes at broad scales, and develop hypotheses about how the system operates when manipulated.

\section{Social-Ecological Systems}

Observations, assessment, theory, and their integration with management and policy currently exist at local scales (e.g., individual projects; [30-32]), mesoscales (e.g., jurisdictional or watershed boundaries; [33,34]), and landscape scales (e.g., multi-watershed to regional; [35,36]. Social-ecological systems, proposed either conceptually or as a means of analysis, have been developed across many of these scales, e.g., [13,37-39]. The social-ecological system framework proposed here integrates ecosystems, and the goods and services they produce, with management and policy via the crucial linkage through monitoring and assessment (Figure 1) as a means to conceptualize these relationships. We argue that monitoring and assessment is the interface between social and ecological components of macrosystems, and must be integrated into any theory of macrosystem behavior because they influence our perception of ecological structure and function.

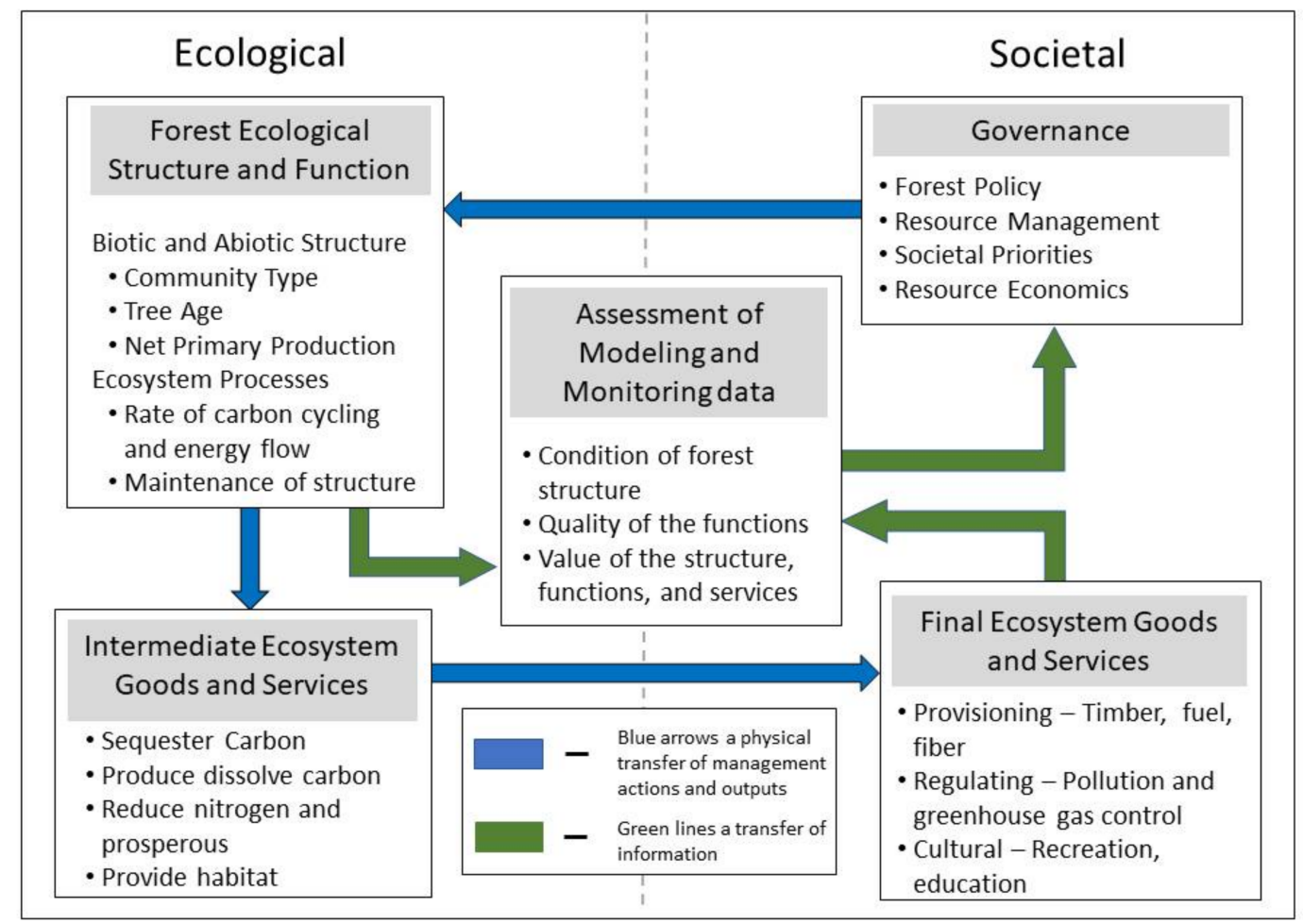

Figure 1. A conceptual model representing a coupled social-ecological forest/human system with the ecological components on the left and societal components on the right. We argue that assessment of modeling and monitoring data provides a link between ecological and societal components of social-ecological systems, and is necessary for developing macrosystems ecological theory, which must incorporate a human component. Bullet points represent examples of ecological and societal attributes.

\subsection{Ecological Systems}

The left side of the social-ecological system framework in Figure 1 represents its ecological elements, the core of which is the theoretical relationship between ecological structure and function [40]. As our understanding of ecosystems developed, e.g., [40-43], structural attributes became defined among ecologists as the composition of the biotic community (e.g., physical and species composition, distribution, biomass), and the quantity and distribution of abiotic materials (e.g., nutrients, water, substrate). These structural attributes interact to support a variety of ecosystem functions like the 
rates of energy flow and nutrient cycling, and the production of additional structure sensu $[40,43]$. Late in the Twentieth Century, ecologists began examining the resilience and stability of systems across scales through the disturbance/recovery fluctuations driven by natural disturbance dynamics [44-48]. The dynamic interaction between structure and disturbance regimes results in either a sink or source of products (e.g., energy, nutrients, or additional structure), which support other ecosystems. Some of these products are transferable through direct connections across ecotones, like the exchange of carbon from terrestrial to aquatic systems [49,50], or indirectly via teleconnections, like the influence of Amazonian deforestation on global climate [51-53].

These sink and source products, necessary to maintain ecosystems, are recognized in the Millennium Ecosystem Assessment classification of ecosystem services [54] as supporting services. Ecosystem services are the goods and benefits that ecosystems provide to support human well-being [54]. However, subsequent literature postulated that, although supporting services produce natural capital, they do not directly support human well-being and are therefore considered 'intermediate services' that are fundamentally necessary for final provisioning, regulating, and cultural services, to exist [55-57].

\subsection{Sociological Systems}

When the natural capital produced by ecosystems is combined with the opportunity for humans to interact with that natural capital, then ecological-based goods and benefits are produced that make provisioning, regulating, and cultural services [54,58,59]. Ecological services are essential for economic prosperity [60] and their maintenance is central to policy and management directives (see Figure 1). In many ways, these directives attempt to control ecological perturbations that occur when disturbances exceed the adaptive range of ecosystems $[46,61,62]$ through rules and regulations that limit or mitigate disturbances that are considered damaging [63]. Some resource-based forest management approaches use perturbations (e.g., timber harvest) and recovery (e.g., replanting) in an attempt to mimic these natural disturbance $[8,9,64]$, further emphasizing the link between ecosystem theory and economic outcomes.

Global change has the potential to alter the flow of goods and benefits from ecosystem services [65]. Through our emerging ability to observe forests at large scales, contemporary literature in forest ecology is replete with catastrophic accounts of the alteration of forested ecosystems resulting from anthropogenic drivers, e.g., [66-68], and dire predictions of future consequences, e.g., [69-71]. The public has understandably responded [72,73], leading to new social-ecological management goals and informed strategies to adaptively manage forests-including emerging novel ecosystems-in an era of global change [26-28]. These new goals open an opportunity to develop assessment approaches to determine if forests can continue to provide the quality and quantity of ecosystem services necessary to meet the public's needs.

\subsection{The Bridge between Ecological and Social Systems}

The monitoring and subsequent assessment of the ecological response to management decisions is central to the relationship among ecological science, ecological management and policy, and the quality and quantity of services the system produces (Figure 1). Assessment interprets the complexity of ecological data to aid policy and management decisions $[23,25]$. To facilitate this process, multiple assessment methodologies have been developed that rely on indicators to measure how components of ecological structure recover toward (or diverge from) a state relatively free of the effects of human activities [23,74-76]. Ideally, these assessments measure the system's ability to sustainably support the production of desired ecological goods and services and economic benefits [54,58].

Ecological assessment approaches are nearly as old as the science of ecology [77], and were developed in parallel with—and benefited from — the foundational developments within the field $[7,78,79]$. From its advent nearly two centuries ago (Box 1), ecological assessment has been used to bridge the gap between ecological function and societal response. As our awareness of the complexity and scale 
of environmental problems has increased over time, so has the sophistication and scale of the assessment tools. There is a long history of assessment approaches developed to facilitate regulatory actions at site and ecosystem scales, e.g., aquatic systems: [80-82], and recently, an emergence of landscape-to-macroscale assessment approaches in the satellite era [34,83-85]. Today, these assessments are applied throughout the world to provide politicians and resource managers with ecological information relevant to management decisions, to communicate those decisions to the public $[25,86]$, and support refinement of the regulatory process [87]. Moving forward, into an uncertain and non-stationary future, assessments will need to evolve into tools for explicitly making ecological forecasts [88]. Focusing on near-term forecasts (on management timescales), and iteratively updating these forecasts as new information becomes available, has the potential to simultaneously provide better information to decision makers while accelerating our pace of ecological understanding [89].

The development of assessment and forecasting tools follows our concern with and understanding of ecological systems. To develop assessment approaches that assist in newly informed strategies to adaptively manage forests, we need to build a general understanding of macroecological structure and function [13], establish which ecological services macrosystems produce [12], and further develop assessment tools to effectively manage Earth system services. This effort is constrained by a lack of information about the suite of forest structures and functions that operate at macroscales, the dynamics of social-ecological relationships at these scales, and the effects of cumulative management decisions on ecosystem processes and services $[11,37,90]$.

To explore this gap in understanding, we will briefly describe two existing macroscale initiatives: large scale habitat conservation connecting the Greater Yellowstone Ecosystem to the Yukon River (Y2Y), and cumulative regional efforts to optimize terrestrial carbon sequestration in the Pacific Northwest. Each initiative uses landscape and macroscale data to inform management actions at local scales that maximize specific ecosystem processes and their related ecological services. These examples also motivate a discussion of how existing and emerging social-ecological theories can guide our understanding of macroscale human-forest interactions, and how to best fill gaps in our theoretical understanding of these dynamics.

Box 1. In the mid-19th century, the smell from industrial and sewage discharge into the Thames was so intense that vinegar soaked sheets were hung from the windows in the Houses of Parliament [91]. At nearly the same time, the impacts on other critical ecological services such as the loss of salmon-an important food source-and increase of water-born human diseases led to legislative actions in Great Britain through the Gas Works Clauses Act of 1847, the Salmon Fisheries Acts of 1891 and 1895, and the Royal Commissions on Prevention of River Pollution in 1857 and Sewage Disposal in 1898 [92]. These commissions established early scientific monitoring of river systems. The assessment of these monitoring data established chemical, physical, and biological criteria to inform management strategies [79,92,93]. In this interaction among public need, management response, and scientific support, the loss of ecological services provided by the Rivers of Great Britain became the focus of early resource management.

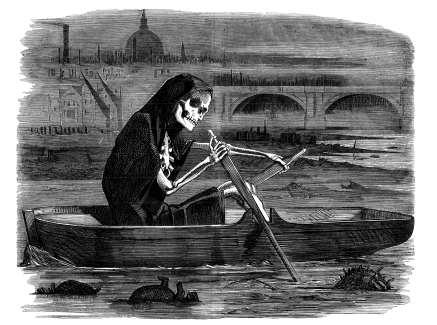

“The Silent Highway Man" [94]. Cartoon from Punch Magazine in 1858 depicting Death claiming the lives of those who are complicit in polluting the RiverThames. 


\section{Examples of Macroscale Forest Management}

\subsection{Habitat}

Not only have rates of animal extinctions accelerated in recent years [95], but many extant populations have declined markedly due to habitat loss or degradation [6]. Many conservation plans prioritize connected landscapes to benefit wildlife [96,97]. Several North American conservation initiatives do so by creating networks of protected lands [20], among them the Yellowstone-to-Yukon Conservation Initiative (Y2Y) [22], an example of a macrosystem-specific initiative that spans political, management, climatic, governmental, and ecosystem boundaries.

The Y2Y initiative began in the 1980s through mutual scientific and political interest in applying conservation biology concepts to protect habitats and expand conservation across large scales [98]. Today, the Y2Y conservation area is approximately 1.2 million $\mathrm{km}^{2}$ in extent and follows the spine of the Rocky and Mackenzie Mountains in the US and Canada. The Y2Y footprint covers two countries, five U.S. states, four Canadian provinces and territories, and over 30 Native and First Nations lands. The conservation effort itself has approximately 300 partner groups that work toward connecting and protecting intact habitats within the $\mathrm{Y} 2 \mathrm{Y}$ footprint. From its initiation, protected habitat area within the $\mathrm{Y} 2 \mathrm{Y}$ boundary has expanded from $11 \%$ to $21 \%$, and conservation management has been expanded by an additional $30 \%$ in comparison to its original extent [22]. These conservation management actions are made up of a series of actions that occur at local (e.g., working with private land owners for conservation easements), to regional scales (e.g., policy development and wildlife friendly road design) [22].

To plan and prioritize conservation actions, the planners use multispecies habitat assessment approaches, e.g., $[35,99,100]$, made of a suite of habitat attributes that may be important to the life cycle of a single species or cross-over to multiple species to determine the quality and extent of habitat within the $\mathrm{Y} 2 \mathrm{Y}$ footprint. To maximize the support of a macroscale ecosystem function such as 'maintenance of megafauna habitat', conservation scientists first determine which macrosystem structural attributes are essential for this function. Empirical relationships between system structure and fauna are determined through studies of biotic and abiotic habitat elements necessary to support, i.e., [98,101-104], or be detrimental to the fauna that inhabit these areas, i.e., [99,105-107].

Each species has a suite of habitat needs that do not necessarily overlap with other species [99], which makes regional conservation planning on a species-by-species basis inefficient [108]. Yet a number of habitat attributes benefit multiple species. For example, species-habitat relationships for fisher (Martes pennanti), lynx (Lynx canadensis), and wolverine (Gulo gulo), exhibit habitat attributes (e.g., regional-scale vegetation, climatic, topographic, and human-impact variables) that may govern distribution patterns of all three species within the Y2Y footprint [99]. Data act as a guide for conservation actions targeted at these cross-over habitat attributes, but data may be so limited that managing for them may not be sufficient to protect other sensitive species [108].

Observations of habitat usage within the $\mathrm{Y} 2 \mathrm{Y}$ footprint guide the development of protected areas. The Y2Y initiative uses a macroscale perspective to guide the conservation vision, but relies on the cumulative actions of local to landscape conservation actions to achieve this vision. As we relate this example to Figure 1, those actions are governed by conservation management intended to shape the composition of ecosystem structure to enhance megafauna habitats. The intent of the initiative is to enhance conditions to support those species and ideally increase the ecological services that benefit humans due to the increased megafauna populations. However, it is unclear how these efforts contribute to or hinder other forest processes and related services that are important to other aspects of the macroscale social-ecological system including, for example, the biogeochemical functions of forest macrosystems. 


\subsection{Carbon Sequestration}

A primary forcing gas driving anthropogenic climate change is carbon dioxide, now at its highest atmosphere concentration in at least 800,000 years [109]. Considering the net negative impact climate change has on ecosystems and society, world governments continue to discuss global policy to manage and reduce the atmospheric concentration of such greenhouse gasses. The 2016 Paris Agreement of the United Nations Framework Convention on Climate Change (UNFCCC) requires that all ratifying parties contribute toward keeping the global average temperature well below a threshold of $1.5^{\circ} \mathrm{C}$ above pre-industrial levels [21]. Although the US federal government plans to pull out of the Paris Agreement in 2020 [110], many regions of the US have vowed to keep the Paris climate accord intact $[111,112]$.

In western North America, the West Coast Regional Carbon Sequestration Partnership (Westcarb: [113]) is a collaborative project involving over 100 public agencies, universities, private companies, and nonprofits throughout western North America that identify opportunities to reduce atmospheric $\mathrm{CO}_{2}$ concentrations. Increased carbon sequestration in terrestrial sinks is one viable contribution to this goal [114], of which forests play a disproportionate role. Globally, the forest carbon sink has averaged 2.4 gigatonnes per year during the period 1990-2007 [115], and forests and forest products currently offset 12-19\% of greenhouse gases from fossil fuel emissions in the U.S. [116]. To take advantage of this forest carbon sink, Westcarb includes forest management opportunities within their suite of small-scale actions that cumulate to Westcarb's macroscale goal [113].

To measure the effectiveness of collective management actions such as Westcarb's, approaches developed to assess changes in forest carbon stocks based on the condition of a suite of structural attributes are necessary to support this ecosystem function, such as 'macroscale storage of forest carbon'. Empirical forest inventories estimate carbon stock in forest that have some diversity of structure using attributes such as live trees, standing dead trees, understory vegetation, down deadwood, forest duff, and soil, i.e., [116-119]. Several carbon budget models are used for western North American forests [113,120-122]. Inventories and models also identify structural attributes that are detrimental to forest carbon stocks such as clearing forests for agriculture, production of short-lived trees for commercial forest products such as paper, and removal of noncommercial products such as standing deadwood, i.e., [123-126].

In relation to Figure 1, it is these assessments that provide information to help guide management approaches to shape forest composition to maximize carbon sequestration. Organizations like Westcarb encourage forest landowners to incorporate management strategies to increase carbon sequestration by avoiding deforestation, increasing afforestation, increasing harvest intervals, planting genetically improved trees, encouraging rapid tree regeneration, reducing fire threats, and increasing the use of forest products $[113,116]$. These structural and functional attributes interact with other macroscale management goals, for example, wildlife habitats in the case of the Y2Y example, which emphasizes how macroscale management can be beneficial or detrimental to different attributes that society values.

\section{Macroscale Forest Management as a Macrosystem}

\subsection{Assessment and Macrosystem Ecology}

The two initiatives examined focus on maximizing an individual forest function, habitat integrity, or carbon sequestration at large scales. These initiatives rely on monitoring and modeling efforts designed to assess their abilities to achieve their goals. How can we effectively assess a system's ability to maintain multiple forest macrosystem functions at these scales? Forests have a finite number of biotic and abiotic structural attributes that support a finite number of macrosystem functions. Consider a simplified model where several forest attributes are shared to maintain both megafauna habitats and carbon sequestration (Figure 2). These include, for example, forest species composition for habitat $[113,121,127,128]$, and fire extent $[113,129]$. In addition, attributes are potentially not shared (Figure 2), such as permanent snow fields [107] and distance from forest edge [128] necessary for 
wolverine and Lynx (Lynx canadensis) denning habitats, respectively, as well as belowground biomass as a measure of carbon sequestration [121].

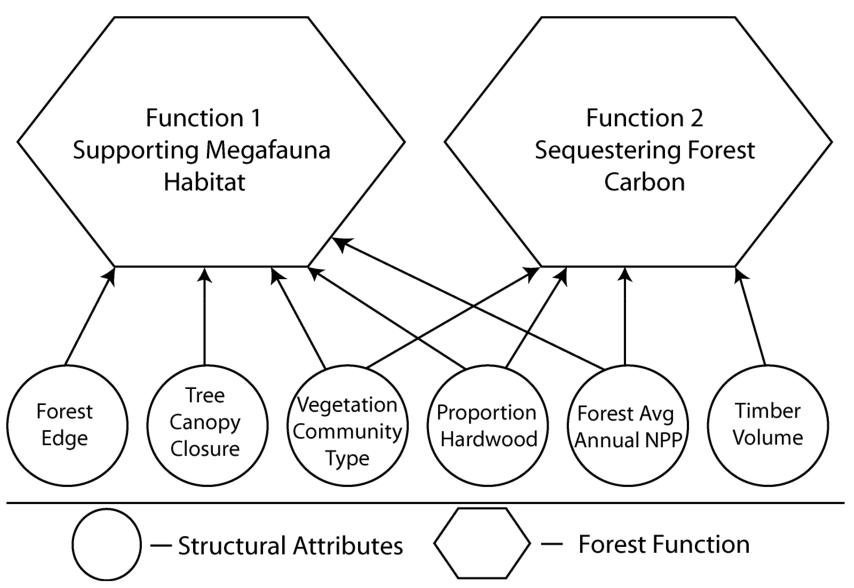

Figure 2. Ecological attributes can be combined in a variety of ways to perform different ecological functions. For example, the attributes Forest Edge and Tree Canopy Closure are needed to support the "Maintenance of Megafauna Habitat" function, along with Vegetation Community Type, Proportion of Hardwood, and Forest Average Annual Net Primary Production (NPP), which are attributes that are shared with the "Sequestering Forest Carbon" function. Information on the attribute Timber Volume is also needed to determine the condition of this latter function.

Forbes [41] conceptualized such an interaction of ecosystem attributes when he described a (lake) system as, "a little world within itself-a microcosm within which all the elemental forces are at work and the play of life goes on in full, but on so small a scale as it to bring it easily within the mental grasp." In many ways, when we attempt to understand and explain ecosystems, even macrosystems, we still adhere to the microcosm approach despite the scale at which it is applied. Although it may be simplistic to treat macroscale complexities with microcosm approaches, applying the microcosm concept to gain a 'mental grasp' is effective in translating scientific knowledge to resource management, and in communicating those decisions to the public $[25,86]$. We are not limited conceptually by large-scale and cross-scale complexities [130-132], nor are we (usually) limited by our computational abilities to test macrosystem hypotheses [133-136]. Rather, we remain limited in our ability to apply these complexities to large-scale management solutions [25]. Assessment helps us obtain this mental grasp of complex systems by providing a tool to translate ecological data for management application [23].

Numerous inventory, monitoring, and assessment tools already exist that measure the quality of ecosystem functions based on multi-metric approaches (Figure 2) to support policy and management decisions at site to watershed scales [80-82,137-139]. Following the framework provided in Figure 1, these approaches examine relationships between system structure and the condition of structural attributes to make determinations of the condition of the functions they support. This information is then made available to the public and decision makers.

Although these assessment approaches exist, it is also recognized that additional scientific knowledge by itself does not necessarily help management and policy makers make sustainable decisions [140-142]. The quality of assessment approaches alone does not determine their actual use in management and policy [25]. In fact, a major governance challenge is connecting the scale at which assessments occur, to the scale at which managers act [143]. Management and policy decisions are driven by a combination of political contexts, social values, available technologies, established infrastructure, and economics, as well as scientific knowledge [142,144]. This is supported by, for example, the Millennium Ecosystem Assessment that tightly links the human condition to environmental conditions [54,145]. Recognizing this linkage has led to a body of literature that addresses conflicts in planning for sustainability efforts and the potential trade-offs across the 
multi-functions of ecosystems and their related services [146-149]. However, from the standpoint of conflicting objectives (Figures 1 and 2), how do we improve our understanding of the social-ecological macrosystem and connect this information to decision-making? We discuss opportunities to advance our theoretical understanding of social-ecological macrosystems by again considering the habitat and carbon sequestration examples.

\subsection{Potential Contested Social-Ecological Values and Conflicted Management}

The habitat and carbon sequestration case studies represent two conservation initiatives that overlap in space and time, yet do not necessarily share the same management entities or goals or share monitoring and assessment tools to guide these directives. Thus, they may be in harmony or at odds with each other, and it is critical to understand the interplay between macrosystem attributes for their effective management. For Y2Y to achieve their conservation goals, they must not only prioritize and acquire high quality habitats strategically dispersed across a large landscape [22], but also collaborate or unintentionally compete with other conservation goals to implement policy and management actions that would influence the composition, structure, and function of the macrosystem.

For example, forest edge, post fire habitat, and mature forest stands are important habitats for $Y 2 Y$ megafauna $[101,128,150]$. However, from the perspective of an organization like Westcarb, less forest edge, reduced fire frequency, and rapidly growing forests with high NPP tend to be better for carbon sequestration $[113,118,121]$. If these large areas are primarily managed for carbon sequestration, then the megafauna habitat may not reach its maximum potential and vice-versa (Figure 3).

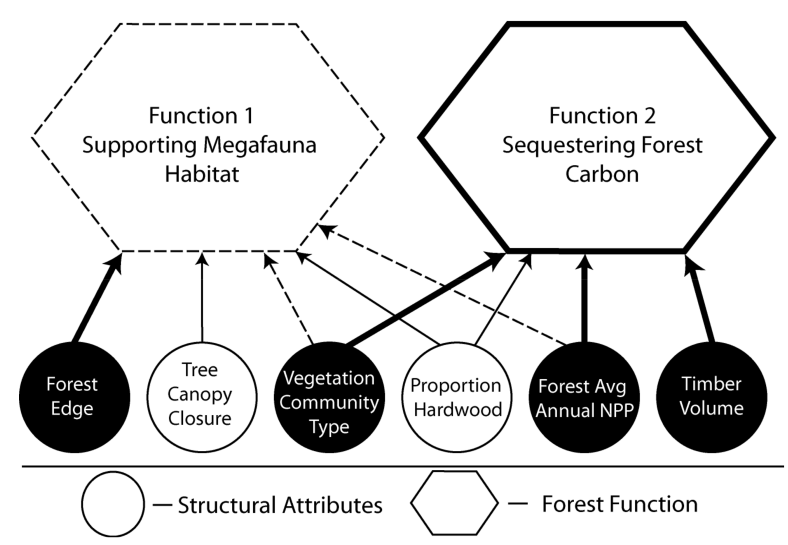

Figure 3. Conceptual tradeoffs in the condition of ecological functions when certain attributes are enhanced to meet a management goal. In this example, circles filled with black are the managed forest structural attributes and unfilled circles are unmanaged attributes. In this example, the attributes Forest Edge, Vegetation Community Type, Forest Average Annual NPP, and Timber Volume are managed to meet different agendas and Tree Canopy Closure and Proportion of Hardwood Cover Types remain unmanaged. Bold lines represent enhanced contribution to function, solid lines without bold represent no change, dashed lines a weakened contribution.

Westcarb and Y2Y have specific goals, but most forests at plot to landscape scales are owned and managed by public and private entities with diverse management goals that range from maintaining wilderness to producing specific types and volumes of timber. This creates a diversity of forested ecosystems, with some providing a suite of supporting, cultural, provisioning, and regulating ecosystem services, while others maximize provisioning services for wood and fiber [12]. Collectively, each diverse management goal at these smaller scales results in a range of forest patches of different structural composition, each designed to satisfy scale-specific objectives. However, they may not satisfy contemporary or future ecological service requirements from ecosystem functions operating at coarser macroscales, such as the 'maintenance of megafauna habitat' or 'macroscale storage of forest carbon', as described in the examples above. They may also contribute to or conflict with emerging 
macrosystem functions like 'macroscale attenuation of weather and climate', which is only recently being understood [151,152]. All this is further complicated by a lack of meaningful measures of the effects resulting from the compilation of diverse, management driven forest patches on these larger scale functions.

\section{Forest Macrosystem Management Research Frontiers}

As we begin to examine macroscale forests for multiple functions beyond the examples above, this logically leads to three important lines of inquiry: (1) What functions operate at macroscales-what are the necessary structural components, scale-dependent or otherwise, that support them, and how do we observe them? (2) How resilient are systems at one scale if altered at another scale (cross-scale interactions and teleconnections)? and (3) How do we effectively measure cross-scale interactions and communicate macrosystem challenges to policy and management? We discuss each in the context of existing and emerging social-ecological theories to provide a framework for understanding multi-scale human-forest interactions.

\subsection{What Functions Operate at Macroscales and What Are the Structural Components, Scale-Dependent or} Otherwise, That Support Them?

Forests across multiple scales can be envisioned as a series of levels (hierarchies) that are formed from the interactions among a set of system attributes that share similar rates of change (viz. [13,39] and spatial extent $[38,153]$. Each hierarchical level in this construct would be represented by the structure and function box within Figure 1. Each level communicates a set of information or quantity of material to the levels above or below. It is assumed that this composition is made up of a subset of scale-dependent structural attributes that will emerge or lose relevance as overall ecosystem structure changes across different scales [132], yet another subset of forest attributes may have relevance across all scales [154]. As these attributes interact to support ecosystem processes, it follows that some set of ecosystem functions apply across all scales, such as carbon sequestration. These functions may also operate in different ways as ecological structure changes with scale ('emergent properties'), while other functions may be wholly scale-dependent and appear or become irrelevant at different scales, such as micro-climate variability (Figure 4).

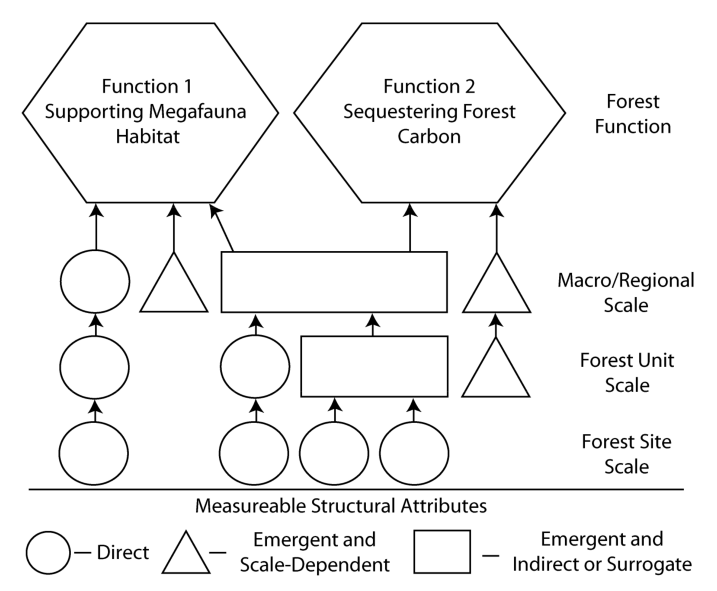

Figure 4. Different structural elements necessary to maintain forest function may potentially be scale dependent or independent. Some structural elements scale with the size of the system (represented as circles, e.g., biomass), although that scaling my not be linear. Other elements emerge at a larger scale (represented as triangles, e.g., fragmentation), while some are a composite of a smaller scale structure (represented as rectangles, e.g., patchiness). As the structural element is managed at the forest or unit scale, it affects the composition of the structure at larger scales and ultimately the functions that are performed at these scales. 
Because after crossing thresholds our cumulative management actions at smaller scales will meaningfully impact the structure and function of forests at macroscales [12], a priority of future forest management research is to define what structural components operate at different hierarchal scales and how they influence scale-dependent functions at these scales. Furthermore, understanding the interactions between scales, i.e., how to link smaller-scale attributes that emerge to become important at larger scales and larger-scale attributes that also govern smaller-scale behavior, is critical to quantifying these multiscale processes [155], as is a framework by which to couple human activities and forest processes.

A hypothesis going forward is that macroscale human-environment interaction has the same structural attributes as the "umwelt" framework of von Uexküll [156], but at different scales and using different sensors to react to environmental change. The original umwelt concept [156], and subsequent research in bio- and eco-semiotics [157-159], conceives of an actor (originally an organism) that reacts in response to environmental cues. As we transition from plot to landscape to macroscales, this interaction takes a different form: the lens by which we observe these increasing scales of actor/response behavior is increasingly via remote sensing, and our response is via policy and management initiatives that must be reliant on assessment as the scale increases. In this way, the human-environment, actor/response, interaction at macroscales is a property that is coupled with interactions at smaller scales, yet emerges as a new property as those coupled components become cumulative (rectangle boxes in Figure 4).

To observe these, a different set of tools and assessment indicators are required at macroscales than are currently used at the plot-to-landscape scales by which we typically interact with forests. The development of macrosystem assessment tools that encompass human/forest interactions (Figure 1) relies on scale-dependent components that not only challenge conceptual frameworks of the system, but require us to address the quality and quantity of the scale-dependent data, the sensors that provide those data, and the cross-scale relationships of those data and their sensors.

\subsection{How Resilient Are Systems at One Scale If Altered at Another Scale (Cross-Scale Interactions)?}

Panarchy theory $[47,132]$ provides a framework to examine cross-scale linkages and interdependencies. A key hypothesis that supports panarchy is that changes to small-scale attributes should sometimes control system dynamics as bottom-up controls [132,160]. The panarchy model also suggests that cross-scale interactions only occur during key phases of ecological change and often result in non-linear dynamics including threshold behavior $[47,154]$. The composition and distribution of system functions maintain system dynamics and resilience against such changes [161]. This concept is particularly important as forested systems begin to change and adapt to larger scale disturbances driven by climate change. These changes will occur either naturally or through small-scale adaptive management efforts. It is these cumulative small-scale efforts that can potentially trigger cross-scale interactions resulting in non-linear dynamics including thresholds.

Climate change has both top-down and bottom-up control on forest systems from both large and small press (e.g., increased temperatures) and pulse (e.g., fire occurrence) disturbances. Under a continually changing climate, forest species will be displaced and lost [162,163], existing forests will undergo greater temporal and spatial variance in disturbances [164-166], some forests will be replaced by other types of ecosystems [167], and some other ecosystems will be replaced by forests. A set of these changes will be due to the direct effects of climate change on the physiology and reproductive behavior of trees [168], insects [67], diseases, and other biota [169] and their interactions. Other changes, such as wildfire and windstorm regimes $[166,170]$, will affect forest composition and sometimes eliminate forests-at least temporarily.

Furthermore, climate change elicits social responses with forest management implications. As the changing climate begins to shift the structure, composition, function, and, in some cases, distribution of forests, managers are reexamining former established management strategies based on ecological sustainability, historic variability, and ecological integrity [171,172]. Managers acknowledge that the continued use of principles established under an assumed stable climate regime will lead to forests that 
are ill-adapted to future conditions. Millar et al. [26] summarize strategic approaches to address shifting forest composition including managing for: resistance to undesired effects, resilience to improve the capacity of the system to return to prior conditions after the disturbance dissipates, and adaptation to intentionally accommodate change and to facilitate the transition to novel ecosystems. We would also argue that the latter strategic approach would likely be driven by economic decisions that, although internally consistent and mathematically sophisticated, may lack consistency with the more holistic requirements of ecosystems [173].

As further global change appears inevitable, different policy or stakeholder agendas will guide forest managers on specific strategic paths [26]. Effective management actions will be coupled with changing climate-based disturbances within the macrosystem. Forests are already managed at the unit scales to satisfy management agendas that range from approaches that maximize a single service (e.g., timber production on private forest land), to forests with a balance of services (e.g., multiple-use public lands), and to lands that are managed to allow natural processes and fluctuations of ecosystem function (e.g., wilderness areas) [12].

At a macroscale, the cumulative effects of these dispersed approaches determine macrosystem composition and distribution, and thereby function. Changes in these collective management approaches may impact emergent properties across scales (see Figure 4); namely, decisions made at stand scales across macrosystems will impact the entire macrosystem. However, until we define the composition of macroscale structural attributes and their resulting functions, we cannot define the composition of the ecological goods and services that operate at these scales (Figure 5). Nor can we determine if cumulative land-use decisions create a macroscale function and service composition that is spatially averaged across each macrosystem sub-unit (i.e., linear scaling), and if the impacts of small-scale decisions are dampened or amplified at larger scales. Additionally, until we define these components, we cannot determine their resilience under different management strategies.

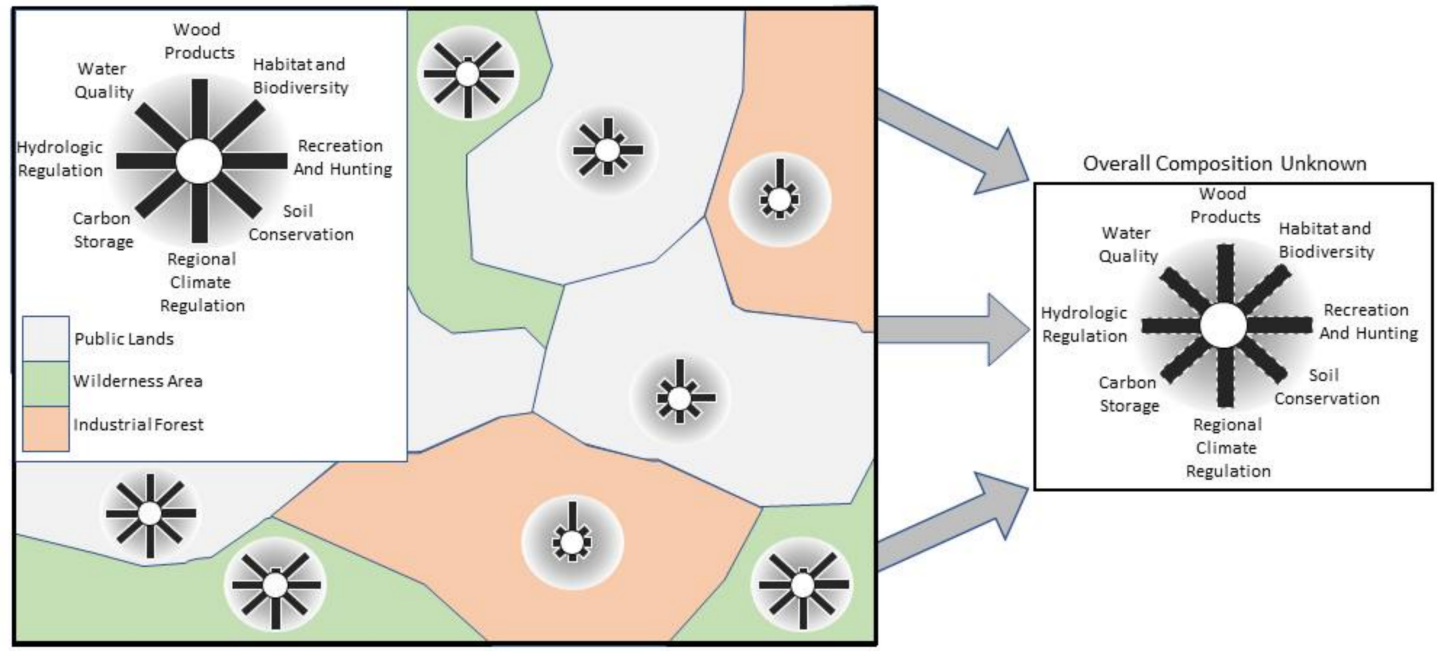

Figure 5. The cumulative effects of decisions across parts of macrosystems on the entire macrosystem are unknown. The daisy symbols represent the potential distribution of ecosystem services in each land cover polygon. Are the ecosystem services by a macrosystem forest simply the spatial average of each individual land-use decisions made at each macrosystem sub-unit (i.e., linear scaling)? Are the impacts of small-scale decisions dampened at larger scales, or are they amplified?

\subsection{How Do We Effectively Measure Cross-Scale Interactions and Communicate Macrosystem Challenges to} Policy and Management?

How then do we test which changes to small-scale attributes control system dynamics from the bottom-up? Following Figure 5, how do management decisions scale in space? Because we cannot experiment directly at the macrosystem scale as opposed to the plot and watershed scales, 
e.g., [44], we must rely on ecosystem models to explore the collective impacts of small-scale changes, or lack thereof. Therefore, to test the scale-dependence of ecological theory, we must develop models that capture stand-scale forest management strategies, including production and ecological forestry, and apply them at the macroscale [12]. Models provide the ability to move from passive monitoring to well designed, question-based monitoring across ecological scales to answer macrosystem scale questions [174,175]. The design of broader scale monitoring programs allows us to test the ecological understanding of a large-scale system through such models [176].

Assessment is another phase in this process from questions to hypotheses to models to monitoring to prediction. As far back as the Rapid Bioassessment Protocol [23], most assessment approaches have relied on the relationship between structure and function to convert (monitoring) observations of an ecosystem's structural attributes into indicators of perturbation. Many attributes have no observable response to perturbation [23], but the ones that do are considered indicators of that response. These indicators are then converted to metrics by assigned values (e.g., $0-1$ or $0-100$; viz [177]) that relate to their location across a disturbance gradient. The assessment approach alluded to in Figures 2-4 would combine these metrics in an ecological meaningful manner to create a multi-metric assessment of the condition of the function.

Assessment can form a bridge between ecological understanding and societal objectives (Figure 1). The growing field of sustainability science focuses on the complex interaction within coupled human and ecological systems to guide management trajectories and promote sustainability [140-142]. Many sustainability scientists argue that more science is not necessarily the best way to address resource management problems; rather, a transdisciplinary approach is needed to achieve sustainable solutions that address both the complexity of problems and decision-making in large social-ecological systems $[16,142,178,179]$.

This approach is valid at management scales where the public desires provisioning of goods and services, and where ecological theory helps us manage ecosystems to provide ecosystem services. However, as displayed in Figure 1, we argue that there is an iterative process in which understanding complex social-ecological macrosystems requires hypothesis-driven science to refine our understanding of the relationship within ecosystem structure and function and between ecosystems and humans across multiple scales. As we develop a more detailed understanding of how scale, bottom-up management, and large-scale global change drivers change the composition of the system, we can then develop scale-specific models, monitoring efforts, and ultimately assessment and forecasting tools.

Each component is iterative, and each is central to understanding how humans and the environment interact at the macrosystem scale. Yet, even with these tools, there are numerous obstacles to coordinating action towards a common goal across jurisdictions that will also have their own goals, some of which may compete both horizontally across jurisdictions and vertically across ecosystem services that are relevant at different scales. Many of these obstacles are driven by economics.

The assessment of forested macrosystems will increasingly involve an understanding-and even perhaps a monetization [180] -of the ecosystem services that they provide, e.g., [181]. At the scale of macrosystems, these services might be better described as Earth system services, e.g., [182]. The notion of ecosystem services has fundamentally altered sustainability science by providing forest managers with a conceptual linkage between the ecological process and human well-being through economic relationships [72,183].

The global costs of climate change have been estimated [184] and the economic values of individual ecosystems have been estimated globally $[180,185]$. Economic theory must therefore play a role in the management of forested macrosystems, which by definition, include humans. Monetizing trade-offs between wildlife habitat and carbon storage, to return to our previous case studies, may result in unpalatable compromises amongst groups that value one service over another. Because macrosystems include human systems, the intersection between economics and ecology must be better understood to simultaneously provide for human and Earth system well-being now and in the future. There are a small but growing number of forest ecosystem service assessment 
approaches that measure the quality of the services produced [186] and the monetized valuation of those services [187]. These currently exist at local to watershed scales, but can be adapted to macrosystem assessment approaches.

\section{Summary and Future Directions}

As we begin to consider the implications of global change on forests at regional to continental scales, we are called upon to understand macroscale social-ecological systems using ecological theory, economics, governance, and resource management. This understanding is necessary to create goals and strategies to adaptively manage forests and emerging novel ecosystems. To facilitate these important macroscale forest management goals, we suggest that the scientific community provide three important components: (1) effective theories for macroecological systems that allow for productive abstract analysis; (2) empirical tests of these theories; and (3) interpretive assessment and, ultimately, forecasting tools that integrate science with management and public opinion.

\subsection{Component 1-Theory}

The first component leads to an initial question (Q1): What functions operate at macroscales, what are the necessary structural components that support them, and how do we observe them? To approach the question, we borrow from von Uexküll and Mackinnon's [156] conceptual framework of how an organism reacts in response to the environmental cues based on the worldview of the organism. The worldview is determined by the organism's ability to perceive its surroundings and the scale at which the organism interacts with its surroundings. For the case of macrosystems, it may be argued that humans act as management entities that respond to ecological observations, increasingly via remote sensing, and react through management decisions, increasingly at macroscales. In this way, the human-environment interaction is an emergent property that relies on a different set of tools and assessment indicators at macroscales than the plot-to-landscape scales by which we typically interact with forests. Using these semiotic approaches to biological systems, we propose an initial hypothesis (H1) that macroscale human-ecosystem interaction has the same structure as von Uexküll and Mackinnon's worldview (weltanschauung) framework, as we perceive environmental change through the lens of observation networks like satellites and respond through management decisions.

The initial question transitions to the second (Q2): How resilient are these systems at one scale if altered at another scale (cross-scale interactions and teleconnections)? To address this question, we borrow from hierarchy and panarchy literature to propose a second hypothesis (H2), that cumulative dispersed approaches to land management determine, in part, macrosystem composition and distribution, and thereby its function. Expanding on Panarchy Theory, bottom-up changes in these collective management approaches will impact emergent properties across scales; namely, decisions made at stand scales across macrosystems will impact the entire macrosystem. Additionally, top-down changes resulting from global change vectors will shape small-scale forest composition through changes in disturbance regimes and adaptive management approaches.

\subsection{Component 2-Tests}

These hypotheses lead to the second component: empirical tests of these theories based upon the growing body of monitoring and modeling data. Clearly, we cannot experiment directly at the macrosystem scale as opposed to the plot and watershed scales. Therefore, we must rely on ecosystem models to explore the collective impacts of small-scale changes, or lack thereof. However, until we can begin this, we address the third important question (Q3): How do we both effectively measure these components and interactions across different scales and communicate that information to inform policy and management across different scales? To address this question, further research must define the composition of macroscale structural attributes and their resulting functions, as well as the composition of the ecological goods and services that operate at these scales. 


\subsection{Component 3-Interpretive Assessment and Forecasting Tools}

As the social-ecological system framework in Figure 1 implies, our understanding of macroscale structure and functions, the goods and services they produce, and how we manage and shape forests to maintain those are linked by our ability to interpret and predict the condition of the system. Also implied in this framework is the interactive aspect of our understanding.

\section{Conclusions}

We argue that the macroscale social-ecological theories and tests of those theories are iterative with the assessment and forecasting tools that integrate science, management, and public opinion [89]. This iterative process will help shape and refine our understanding of the implications of cumulative management decisions on macroscale forest structure and function relationships, and the desirable macroscale ecological services.

Acknowledgments: We thank Sarah Carter of the U.S. Geological Survey and three anonymous reviewers for their comments during the review of this manuscript We acknowledge funding support from the National Science Foundation (NSF) Emerging Frontiers Macrosystems Biology Program Grants 1241810 and 1702029 to Montana State University, 1241881 and 1702996 to the University of Alabama, 1241860 and 1702835 to the University of Florida, 1241894 to Boston University, 1241814 to the University of Wisconsin-Madison, and 1702676 to Colorado State University. A.R.D. and M.C.D. acknowledge support of NSF Advances in Biological Informatics grants no. 1062204 to the University of Wisconsin-Madison and No. 1062547 to Boston University. PCS acknowledges support from the NSF Office of Integrated Activities grant no. 1632810. This research was also partially supported by the Initiative for Regulation and Applied Economic Analysis at Montana State University. We would also like to acknowledge the thorough review provided by Sarah Carter of the U.S. Geological Survey. Any use of trade, firm, or product names is for descriptive purposes only and does not imply endorsement by the U.S. Government.

Author Contributions: W.J.K. conceived, directed, and coordinated the theoretical foundations of the work with substantial feedback from all authors; as part of a larger forest marcosystems team, all authors contributed to the formulation of management scenarios across large scales; P.C.S. contributed to discussion on hierarchical and symbiotic theory; C.A.S. contributed to concepts of socio-ecological systems and governance; M.W.B., A.R.D., and C.L.S. provided input on macrosystem forest theory; G.S., A.R.D. and M.C.D. contributed to discussion on modeling approaches; D.J.A. Wood contributed to discussion on assessment and landscape ecology; W.J.K. led the writing of the paper, with assistance from all co-authors.

Conflicts of Interest: The authors declare no conflict of interest. The founding sponsors had no role in the design of the study, in the collection, analyses, or interpretation of data, in the writing of the manuscript, or in the decision to publish the results.

\section{References}

1. Steffen, W.; Persson, A.; Deutsch, L.; Zalasiewicz, J.; Williams, M.; Richardson, K.; Crumley, C.; Crutzen, P.; Folke, C.; Gordon, L.; et al. The Anthropocene: From global change to planetary stewardship. Ambio 2011, 40, 739-761. [CrossRef] [PubMed]

2. Bonan, G.B. Forests and climate change: Forcings, feedbacks, and the climate benefits of forests. Science 2008, 320, 1444-1449. [CrossRef] [PubMed]

3. Intergovernmental Panel on Climate Change (IPCC). Climate Change 2013: The Physical Science Basis. Contribution of Working Group I to the Fifth Assessment Report of the Intergovernmental Panel on Climate Change; Stocker, T.F., Qin, D., Plattner, G.-K., Tignor, M., Allen, S.K., Boschung, J., Nauels, A., Xia, Y., Bex, V., Midgley, P.M., Eds.; Cambridge University Press: Cambridge, UK; New York, NY, USA, 2013.

4. Parmesan, C.; Yohe, G. A globally coherent fingerprint of climate change impacts across natural systems. Nature 2003, 421, 37-42. [CrossRef] [PubMed]

5. Peipoch, M.; Brauns, M.; Hauer, F.R.; Weitere, M.; Valett, H.M. Ecological simplification: Human influences on riverscape complexity. BioScience 2015. [CrossRef]

6. World Wildlife Fund (WWF). Living Planet Report 2016. Risk and Resilience in a New Era; McLellan, R., Ed.; World Wildlife Fund: Gland, Switzerland, 2016; ISBN 978-2-940529-40-7.

7. Verdonschot, P.F. Integrated ecological assessment methods as a basis for sustainable catchment management. Hydrobiologia 2000, 422, 389-412. [CrossRef]

8. Bergeron, Y.; Harvey, B.; Leduc, A.; Gauthier, S. Forest management guidelines based on natural disturbance dynamics: Stand-and forest-level considerations. For. Chron. 1999, 75, 49-54. [CrossRef] 
9. Lindenmayer, D.B.; Franklin, J.F.; Fischer, J. General management principles and a checklist of strategies to guide forest biodiversity conservation. Biol. Conserv. 2006, 131, 433-445. [CrossRef]

10. Nelson, E.; Mendoza, G.; Regetz, J.; Polasky, S.; Tallis, H.; Cameron, D.; Chan, K.M.; Daily, G.C.; Goldstein, J.; Kareiva, P.M.; et al. Modeling multiple ecosystem services, biodiversity conservation, commodity production, and tradeoffs at landscape scales. Front. Ecol. Environ. 2009, 7, 4-11. [CrossRef]

11. Parrott, L.; Meyer, W.S. Future landscapes: Managing within complexity. Front. Ecol. Environ. 2012, 10, 382-389. [CrossRef]

12. Becknell, J.M.; Desai, A.R.; Dietze, M.C.; Schultz, C.A.; Starr, G.; Duffy, P.A.; Franklin, J.F.; Pourmokhtarian, A.; Hall, J.; Stoy, P.C.; et al. Assessing interactions among changing climate, management, and disturbance in forests: A macrosystems approach. BioScience 2015, 65, 263-274. [CrossRef]

13. Heffernan, J.B.; Soranno, P.A.; Angilletta, M.J.; Buckley, L.B.; Gruner, D.S.; Keitt, T.H.; Kellner, J.R.; Kominoski, J.S.; Rocha, A.V.; Xiao, J.; et al. Macrosystems ecology: Understanding ecological patterns and processes at continental scales. Front. Ecol. Environ. 2014, 12, 5-14. [CrossRef]

14. Iannone, B.V.; Oswalt, C.M.; Liebhold, A.M.; Guo, Q.; Potter, K.M.; Nunez-Mir, G.C.; Oswalt, S.N.; Pijanowski, B.C.; Fei, S. Region-specific patterns and drivers of macroscale forest plant invasions. Divers. Distrib. 2015, 21, 1181-1192. [CrossRef]

15. About the Action Plans. Available online: https://stateforesters.org/forest-action-plans/about-action-plans (accessed on 19 January 2018).

16. Freeman, O.E.; Duguma, L.; Minang, P. Operationalizing the integrated landscape approach in practice. Ecol. Soc. 2015, 20. [CrossRef]

17. Reed, J.; Deakin, L.; Sunderland, T. What are "Integrated Landscape Approaches" and how effectively have they been implemented in the tropics: A systematic map protocol. Environ. Evid. 2015, 4, 2. [CrossRef]

18. Sayer, J.; Sunderland, T.; Ghazoul, J.; Pfund, J.-L.; Sheil, D.; Meijaard, E.; Venter, M.; Boedhihartono, A.K.; Day, M.; Garcia, C.; et al. Ten principles for a landscape approach to reconciling agriculture, conservation, and other competing land uses. Proc. Natl. Acad. Sci. USA 2013, 110, 8349-8356. [CrossRef] [PubMed]

19. Biermann, F. "Earth system governance" as a crosscutting theme of global change research. Glob. Environ. Chang. 2007, 17, 326-337. [CrossRef]

20. McKinney, M.; Johnson, S. Large Landscape Conservation in the Rocky Mountain West: An inventory and Status Report; Center for Natural Resources \& Environmental Policy; University of Montana-Missoula: Missoula, MT, USA, 2013; p. 28.

21. UNFCCC (United Nations Framework Convention on Climate Change). The Paris Agreement. Available online: http:/ / unfccc.int/paris_agreement/items/9485.php (accessed on 16 January 2017).

22. Y2Y (Yellowstone to Yukon Conservation Initiative). Yellowstone to Yukon Conservation Initiative: Overview and Progress. Available online: https: / /y2y.net/ (accessed on 6 September 2016).

23. Barbour, M.T.; Gerritsen, J.; Snyder, B.D.; Stribling, J.B. Rapid Bioassessment Protocols for Use in Streams and Wadeable Rivers: Periphyton, Benthic Macroinvertebrates and Fish, 2nd ed.; U.S. Environmental Protection Agency, Office of Water: Washington, DC, USA, 1999.

24. Turner, M.G.; Crow, T.R.; Liu, J.; Rabe, D.; Rabeni, C.F.; Soranno, P.A.; Taylor, W.W.; Vogt, K.A.; Wiens, J.A. Bridging the gap between landscape ecology and natural resource management. In Integrating Landscape Ecology into Natural Resource Management; Lui, J., Taylor, W.W., Eds.; Cambridge University Press: Cambridge, UK, USA, 2002; pp. 433-460.

25. Turnhout, E.; Hisschemöller, M.; Eijsackers, H. Ecological indicators: Between the two fires of science and policy. Ecol. Indic. 2007, 7, 215-228. [CrossRef]

26. Millar, C.I.; Stephenson, N.L.; Stephens, S.L. Climate change and forests of the future: Managing in the face of uncertainty. Ecol. Appl. 2007, 17, 2145-2151. [CrossRef] [PubMed]

27. USDA (U.S. Department of Agriculture). 2012 Planning Rule Final Directives for National Forest System Land Management Planning. Available online: http://www.fs.usda.gov/detail/planningrule/home/?cid= stelprd3828310 (accessed on 19 July 2016).

28. Yousefpour, R.; Jacobsen, J.B.; Thorsen, B.J.; Meilby, H.; Hanewinkel, M.; Oehler, K. A review of decision-making approaches to handle uncertainty and risk in adaptive forest management under climate change. Ann. For. Sci. 2012, 69, 1-15. [CrossRef]

29. Gregory, R.; Failing, L.; Harstone, M.; Long, G.; McDaniels, T.; Ohlson, D. Structured Decision Making: A Practical Guide to Environmental Management Choices; John Wiley \& Sons: Hoboken, NJ, USA, 2012. 
30. Arthur, M.A.; Blankenship, B.A.; Schörgendorfer, A.; Loftis, D.L.; Alexander, H.D. Changes in stand structure and tree vigor with repeated prescribed fire in an Appalachian hardwood forest. For. Ecol. Manag. 2015, 340, 46-61. [CrossRef]

31. Loreno, S.; Fried, J.S.; Yost, A. Applying management modeling to assess the feasibility of accelerating landscape restoration on federal forests in Eastern Oregon. In Proceedings of the Pushing Boundaries: New Directions in Inventory Techniques \& Applications; Forest Inventory and Analysis (FIA) Symposium 2015; U.S. Department of Agriculture, Forest Service, Pacific Northwest Research Station: Portland, OR, USA, 2015.

32. Turner, M.G.; Romme, W.H.; Tinker, D.B. Surprises and lessons from the 1988 Yellowstone fires. Front. Ecol. Environ. 2003, 1, 351-358. [CrossRef]

33. Bixler, R.P.; Johnson, S.; Emerson, K.; Nabatchi, T.; Reuling, M.; Curtin, C.; Romolini, M.; Grove, J.M. Networks and landscapes: A framework for setting goals and evaluating performance at the large landscape scale. Front. Ecol. Environ. 2016, 14, 145-153. [CrossRef]

34. Tierney, G.L.; Faber-Langendoen, D.; Mitchell, B.R.; Shriver, W.G.; Gibbs, J.P. Monitoring and evaluating the ecological integrity of forest ecosystems. Front. Ecol. Environ. 2009, 7, 308-316. [CrossRef]

35. Kleindl, W.J.; Hauer, F.R.; Ellis, B.K.; Kimball, K.; Kunkel, K.; Matson, P.A.; Muhfeld, C.; Oyler, J.; Porter, E.; Servheen, C.; et al. A Multi-Metric Watershed Condition Model for Glacier National Park; National Parks Service: Fort Collins, CO, USA, 2015.

36. Mulder, B.S.; Noon, B.R.; Spies, T.A.; Raphael, M.G.; Palmer, C.J.; Olsen, A.R.; Reeves, G.H.; Hartwell, H., Jr. The Strategy and Design of the Effectiveness Monitoring Program for The Northwest Forest Plan; U.S. Department of Agriculture, Forest Service, Pacific Northwest Research Station: Portland, OR, USA, 1999.

37. Binder, C.; Hinkel, J.; Bots, P.; Pahl-Wostl, C. Comparison of Frameworks for Analyzing Social-ecological Systems. Ecol. Soc. 2013, 18. [CrossRef]

38. Folke, C.; Jansson, Å.; Rockström, J.; Olsson, P.; Carpenter, S.R.; Chapin, F.S.; Crépin, A.-S.; Daily, G.; Danell, K.; Ebbesson, J.; et al. Reconnecting to the biosphere. Ambio 2011, 40, 719. [CrossRef] [PubMed]

39. Rose, K.C.; Graves, R.A.; Hansen, W.D.; Harvey, B.J.; Qiu, J.; Wood, S.A.; Ziter, C.; Turner, M.G. Historical foundations and future directions in macrosystems ecology. Ecol. Lett. 2017, 20, 147-157. [CrossRef] [PubMed]

40. Odum, E.P. Relationships between structure and function in the ecosystem. Jpn. J. Ecol. 1962, 12, 108-118.

41. Forbes, S.A. The lake as a microcosm. Bull. Peoria Sci. Assoc. 1887, 15, 77-87.

42. Lindeman, R.L. The trophic-dynamic aspect of ecology. Ecology 1942, 23, 399-417. [CrossRef]

43. Brinson, M.M. Changes in the functioning of wetlands along environmental gradients. Wetlands 1993, 13, 65-74. [CrossRef]

44. Bormann, F.H.; Likens, G.E. Pattern and Process in a Forested Ecosystem; Springer-Verlag: New York, NY, USA, 1979.

45. White, P.S.; Pickett, S.T. Natural disturbance and patch dynamics: An introduction. In The Ecology of Natural Disturbance and Patch Dynamics; Pickett, S.T.A., Ed.; Academic Press: Orlando, FL, USA, 1985; pp. 3-17.

46. Poff, N.L.; Allan, J.D.; Bain, M.B.; Karr, J.R.; Prestegaard, K.L.; Richter, B.D.; Sparks, R.E.; Stromberg, J.C. The natural flow regime. A paradigm for river conservation and restoration. Bioscience 1997, 47, 769-784. [CrossRef]

47. Gunderson, L.H.; Holling, C.S. Panarchy: Understanding Transformations in Human and Natural Systems; Island Press: Washington, DC, USA, 2001; ISBN 978-1-59726-939-1.

48. Stanford, J.A.; Lorang, M.S.; Hauer, F.R. The shifting habitat mosaic of river ecosystems. Verh. Int. Ver. Limnol. 2005, 29, 123-136. [CrossRef]

49. Freeman, C.; Evans, C.D.; Monteith, D.T.; Reynolds, B.; Fenner, N. Export of organic carbon from peat soils. Nature 2001, 412, 785. [CrossRef] [PubMed]

50. Tranvik, L.J.; Jansson, M. Climate change (Communication arising): Terrestrial export of organic carbon. Nature 2002, 415, 861-862. [CrossRef]

51. Avissar, R.; Werth, D. Global hydroclimatological teleconnections resulting from tropical deforestation. J. Hydrometeorol. 2005, 6, 134-145. [CrossRef]

52. Potter, C.; Klooster, S.; Steinbach, M.; Tan, P.; Kumar, V.; Shekhar, S.; Nemani, R.; Myneni, R. Global teleconnections of climate to terrestrial carbon flux. J. Geophys. Res. Atmos. 2003, 108. [CrossRef]

53. Stark, S.C.; Breshears, D.D.; Garcia, E.S.; Law, D.J.; Minor, D.M.; Saleska, S.R.; Swann, A.L.S.; Villegas, J.C.; Aragão, L.E.O.C.; Bella, E.M.; et al. Toward accounting for ecoclimate teleconnections: Intra- and 
inter-continental consequences of altered energy balance after vegetation change. Landsc. Ecol. 2016, 31, 181-194. [CrossRef]

54. Millennium Ecosystem Assessment (MEM). Ecosystems and Human Well-Being: Overview; World Resources Institute: Washington, DC, USA, 2005.

55. Boyd, J.; Banzhaf, S. What are ecosystem services? The need for standardized environmental accounting units. Ecol. Econ. 2007, 63, 616-626. [CrossRef]

56. Potschin, M.B.; Haines-Young, R.H. Ecosystem services: Exploring a geographical perspective. Prog. Phys. Geogr. 2011, 35, 575-594. [CrossRef]

57. Lyons, J.; Navarro-Perez, S.; Cochran, P.A.; Santana, C.E.; Guzman-Arroyo, M. Index of biotic integrity based on fish assemblages for the conservation of streams and rivers in west-central Mexico. Conserv. Biol. Conserv. Biol. Vol. 1995, 9, 569-584. [CrossRef]

58. Boyd, J.; Ringold, P.; Krupnick, A.; Johnson, R.J.; Weber, M.A.; Hall, K.M. Ecosystem Services Indicators: Improving the Linkage between Biophysical and Economic Analyses; Social Science Research Network: Rochester, NY, USA, 2015.

59. System of Environmental-Economic Accounting 2012: Central Framework 2014; United Nations Department of Economics and Social Affairs: New York, NY, USA, 2014; pp. 1-331.

60. Daily, G. Nature's Services: Societal Dependence on Natural Ecosystems; Island Press: Washington, DC, USA, 1997; ISBN 1-55963-475-8.

61. Lake, P.S.; Bond, N.; Reich, P. Linking ecological theory with stream restoration. Freshw. Biol. 2007, 52, 597-615. [CrossRef]

62. Collins, S.L.; Carpenter, S.R.; Swinton, S.M.; Orenstein, D.E.; Childers, D.L.; Gragson, T.L.; Grimm, N.B.; Grove, J.M.; Harlan, S.L.; Kaye, J.P.; et al. An integrated conceptual framework for long-term social-ecological research. Front. Ecol. Environ. 2011, 9, 351-357. [CrossRef]

63. Bosselman, F.P.; Tarlock, A.D. Influence of ecological science on American law: An introduction. Chic.-Kent L. Rev. 1993, 69, 847.

64. Harvey, B.D.; Leduc, A.; Gauthier, S.; Bergeron, Y. Stand-landscape integration in natural disturbance-based management of the southern boreal forest. For. Ecol. Manag. 2002, 155, 369-385. [CrossRef]

65. Nelson, E.J.; Kareiva, P.; Ruckelshaus, M.; Arkema, K.; Geller, G.; Girvetz, E.; Goodrich, D.; Matzek, V.; Pinsky, M.; Reid, W.; et al. Climate change's impact on key ecosystem services and the human well-being they support in the US. Front. Ecol. Environ. 2013, 11, 483-893. [CrossRef]

66. Westerling, A.L.; Hidalgo, H.G.; Cayan, D.R.; Swetnam, T.W. Warming and earlier spring increase western US forest wildfire activity. Science 2006, 313, 940-943. [CrossRef] [PubMed]

67. DeSantis, R.D.; Moser, W.K.; Gormanson, D.D.; Bartlett, M.G.; Vermunt, B. Effects of climate on emerald ash borer mortality and the potential for ash survival in North America. Agric. For. Meteorol. 2013, 178, 120-128. [CrossRef]

68. Weed, A.S.; Ayres, M.P.; Hicke, J.A. Consequences of climate change for biotic disturbances in North American forests. Ecol. Monogr. 2013, 83, 441-470. [CrossRef]

69. Gauthier, S.; Bernier, P.; Kuuluvainen, T.; Shvidenko, A.Z.; Schepaschenko, D.G. Boreal forest health and global change. Science 2015, 349, 819-822. [CrossRef] [PubMed]

70. Trumbore, S.; Brando, P.; Hartmann, H. Forest health and global change. Science 2015, 349, $814-818$. [CrossRef] [PubMed]

71. Millar, C.I.; Stephenson, N.L. Temperate forest health in an era of emerging megadisturbance. Science 2015, 349, 823-826. [CrossRef] [PubMed]

72. Gómez-Baggethun, E.; de Groot, R.; Lomas, P.L.; Montes, C. The history of ecosystem services in economic theory and practice: From early notions to markets and payment schemes. Ecol. Econ. 2010, 69, 1209-1218. [CrossRef]

73. Braat, L.C.; de Groot, R. The ecosystem services agenda: Bridging the worlds of natural science and economics, conservation and development, and public and private policy. Ecosyst. Serv. 2012, 1, 4-15. [CrossRef]

74. Smith, R.D.; Ammann, A.; Bartoldus, C.; Brinson, M.M. Approach for Assessing Wetland Functions Using Hydrogeomorphic Classification, Reference Wetlands, and Functional Indices; U.S. Army Engineer Waterways Experiment Station: Vicksburg, MS, USA, 1995. 
75. Karr, J.R.; Chu, E.W. Restoring Life in Running Waters: Better Biological Monitoring; Island Press: Washington, DC, USA, 1998.

76. Collins, J.N.; Stein, E.D.; Sutula, M.; Clark, R.; Fetscher, A.E.; Grenier, L.; Grosso, C.; Wiskind, A. California Rapid Assessment Method (CRAM) for Wetlands, v. 5.0.2.; San Francisco Estuary Institute: San Francisco, CA, USA, 2008.

77. Cairns, J., Jr.; Pratt, J.R. A history of biological monitoring using benthic macroinvertebrates. Freshw. Biomonit. Benthic Macroinvertebr. 1993, 10, 27.

78. Kolkwitz, R.; Marsson, M. Ökologie der pflanzlichen Saprobien. Berichte Dtsch. Bot. Ges. 1908, 26, 505-519.

79. Dolédec, S.; Statzner, B. Responses of freshwater biota to human disturbances: Contribution of J-NABS to developments in ecological integrity assessments. J. N. Am. Benthol. Soc. 2010, 29, 286-311. [CrossRef]

80. Bartoldus, C.C. A Comprehensive Review of Wetland Assessment Procedures: A Guide for Wetland Practitioners; Environmental Concern Incorporated: St. Michaels, MD, USA, 1999.

81. Diaz, R.J.; Solan, M.; Valente, R.M. A review of approaches for classifying benthic habitats and evaluating habitat quality. J. Environ. Manag. 2004, 73, 165-181. [CrossRef] [PubMed]

82. Fennessy, M.S.; Jacobs, A.D.; Kentula, M.E. An evaluation of rapid methods for assessing the ecological condition of wetlands. Wetlands 2007, 27, 543-560. [CrossRef]

83. Unnasch, R.S.; Braun, D.P.; Comer, P.J.; Eckert, G.E. The Ecological Integrity Assessment Framework: A Framework for Assessing the Ecological Integrity of Biological and Ecological Resources of the National Park System; National Park Service: Washington, DC, USA, 2008.

84. Doren, R.F.; Trexler, J.C.; Gottlieb, A.D.; Harwell, M.C. Ecological indicators for system-wide assessment of the greater everglades ecosystem restoration program. Ecol. Indic. 2009, 9, S2-S16. [CrossRef]

85. U.S. Department of Agriculture (USDA). Watershed Condition Classification Technical Guide; USDA: Washington, DC, USA, 2011.

86. Dramstad, W.E. Spatial metrics-useful indicators for society or mainly fun tools for landscape ecologists? Nor. Geogr. Tidsskr.-Nor. J. Geogr. 2009, 63, 246-254. [CrossRef]

87. Holder, J.; McGillivray, D. Taking Stock of Environmental Assessment: Law, Policy and Practice; Routledge-Cavendish: New York, NY, USA, 2007.

88. Dietze, M.C. Ecological Forecasting; Princeton University Press: Princeton, NJ, USA, 2017; ISBN 978-1-4008-8545-9.

89. Dietze, M.C.; Fox, A.; Beck-Johnson, L.M.; Betancourt, J.L.; Hooten, M.B.; Jarnevich, C.S.; Keitt, T.H.; Kenney, M.A.; Laney, C.M.; Larsen, L.G.; et al. Iterative near-term ecological forecasting: Needs, opportunities, and challenges. Proc. Natl. Acad. Sci. USA 2018, 115, 1424-1432. [CrossRef] [PubMed]

90. Carpenter, S.R.; Mooney, H.A.; Agard, J.; Capistrano, D.; DeFries, R.S.; Díaz, S.; Dietz, T.; Duraiappah, A.K.; Oteng-Yeboah, A.; Pereira, H.M.; et al. Science for managing ecosystem services: Beyond the Millennium Ecosystem Assessment. Proc. Natl. Acad. Sci. USA 2009, 106, 1305-1312. [CrossRef] [PubMed]

91. Gameson, A.L.H.; Wheeler, A. Restoration and recovery of the Thames Estuary [in England, pollution]. In Proceedings of the International Symposium on the Recovery of Damaged Ecosystems, Blacksburg, Virginia, 23-25 March 1975; University Press of Virginia: Charlottesville, VA, USA, 1975.

92. Hynes, H.B.N. The Biology of Polluted Waters; University of Toronto Press: Toronto, ON, USA, 1974.

93. Cairns, J.; Pratt, J.R. A History of Biological Monitoring Using Benthic Macroinvertebrates; Chapman Hall: New York, NY, USA, 1993.

94. The "Silent Highway"-Man. "Your MONEY or Your LIFE!". Available online: https:/ / punch.photoshelter. com/image/I0000AAbdvhDlKGE (accessed on 9 April 2018).

95. De Vos, J.M.; Joppa, L.N.; Gittleman, J.L.; Stephens, P.R.; Pimm, S.L. Estimating the normal background rate of species extinction. Conserv. Biol. 2015, 29, 452-462. [CrossRef] [PubMed]

96. Margules, C.R.; Pressey, R.L. Systematic conservation planning. Nature 2000, 405, 243-253. [CrossRef] [PubMed]

97. Pearce, J.L.; Kirk, D.A.; Lane, C.P.; Mahr, M.H.; Walmsley, J.; Casey, D.; Muir, J.E.; Hannon, S.; Hansen, A.; Jones, K. Prioritizing avian conservation areas for the Yellowstone to Yukon Region of North America. Biol. Conserv. 2008, 141, 908-924. [CrossRef]

98. Chester, C.C. Responding to the Idea of Transboundary Conservation. J. Sustain. For. 2003, 17, $103-125$. [CrossRef]

99. Carroll, C.; Noss, R.F.; Paquet, P.C. Carnivores as focal species for conservation planning in the Rocky Mountain region. Ecol. Appl. 2001, 11, 961-980. [CrossRef] 
100. Apps, C.D.; Weaver, J.L.; Paquet, P.C.; Bateman, B.; McLellan, B.N. Carnivores in the Southern Canadian Rockies: Core Areas and Connectivity Across the Crowsnest Highway; Wildlife Conservation Society Canada Conservation: Toronto, ON, Canada, 2007.

101. Mowat, G.; Strobeck, C. Estimating population size of grizzly bears using hair capture, DNA profiling, and mark-recapture analysis. J. Wildl. Manag. 2000, 64, 183-193. [CrossRef]

102. Carroll, C.; Noss, R.F.; Paquet, P.C.; Schumaker, N.H. Use of population viability analysis and reserve selection algorithms in regional conservation plans. Ecol. Appl. 2003, 13, 1773-1789. [CrossRef]

103. Gross, J.E.; Kneeland, M.C.; Reed, D.F.; Reich, R.M. GIS-based habitat models for mountain goats. J. Mammal. 2002, 83, 218-228. [CrossRef]

104. Cushman, S.A.; McKelvey, K.S.; Schwartz, M.K. Use of empirically derived source-destination models to map regional conservation corridors. Conserv. Biol. 2009, 23, 368-376. [CrossRef] [PubMed]

105. Dood, A.R.; Atkinson, S.J.; Boccodori, V.J. Grizzly Bear Management Plan for Western Montana: Final Programmatic Environmental Impact Statement 2006-2016; Montana Department of Fish, Wildlife and Parks: Helena, MT, USA, 2006; p. 163.

106. Gude, P.H.; Hansen, A.J.; Jones, D.A. Biodiversity consequences of alternative future land use scenarios in Greater Yellowstone. Ecol. Appl. 2007, 17, 1004-1018. [CrossRef] [PubMed]

107. Copeland, J.P.; Yates, R.E.; Ruggiero, L. Wolverine Population Assessment in Glacier National Park; Comprehensive Summary Update; USDA Forest Service, Rocky Mountain Research Station: Fort Collins, CO, USA, 2008.

108. Noss, R.F.; O'Connell, M.; Murphy, D.D. The Science of Conservation Planning: Habitat Conservation under the Endangered Species Act; Island Press: Washington, DC, USA, 1997.

109. Lüthi, D.; Le Floch, M.; Bereiter, B.; Blunier, T.; Barnola, J.-M.; Siegenthaler, U.; Raynaud, D.; Jouzel, J.; Fischer, H.; Kawamura, K.; Stocker, T.F. High-resolution carbon dioxide concentration record 650,000-800,000 years before present. Nature 2008, 453, 379-382. [CrossRef] [PubMed]

110. Trump Will Withdraw U.S. From Paris Climate Agreement. Available online: https:/ /www.nytimes.com/ 2017/06/01/climate/trump-paris-climate-agreement.html (accessed on 15 June 2017).

111. A California-Led Alliance of Cities and States Vows to Keep the Paris Climate Accord Intact. Available online: http:/ / www.latimes.com/politics/la-na-pol-paris-states-20170602-story.html (accessed on 15 June 2017).

112. Regional Carbon Sequestration Partnerships (RCSP) Initiative. Available online: https:/ /www.netl.doe.gov / research/coal/carbon-storage/carbon-storage-infrastructure/rcsp\#westcarb (accessed on 31 January 2018).

113. WestCarb West Coast Regional Carbon Sequestration Partnership. Available online: http://www.westcarb. org / (accessed on 25 January 2017).

114. Justus, J.R.; Fletcher, S.R. Global climate change: CRS issue brief for congress. In Congressional Research Service; Library of Congress: Washington, DC, USA, 2006.

115. Pan, Y.; Birdsey, R.A.; Fang, J.; Houghton, R.; Kauppi, P.E.; Kurz, W.A.; Phillips, O.L.; Shvidenko, A.; Lewis, S.L.; Canadell, J.G.; et al. A large and persistent carbon sink in the world's forests. Science 2011, 333, 988-993. [CrossRef] [PubMed]

116. Ryan, M.G.; Harmon, M.E.; Birdsey, R.A.; Giardina, C.P.; Heath, L.S.; Houghton, R.A.; Jackson, R.B.; McKinley, D.C.; Morrison, J.F.; Murray, B.C.; et al. A synthesis of the science on forests and carbon for US forests. Issues Ecol. 2010, 13, 1-16.

117. Smith, J.E.; Heath, L.S.; Jenkins, J.C. Forest Volume-to-Biomass Models and Estimates of Mass for Live and Standing Dead Trees of US Forests; US Department of Agriculture, Forest Service, Northeastern Research Station: Amherst, MA, USA, 2003.

118. Smith, J.E.; Heath, L.S.; Woodbury, P.B. How to estimate forest carbon for large areas from inventory data. J. For. 2004, 102, 25-31.

119. Woodall, C.W.; Heath, L.S.; Domke, G.M.; Nichols, M.C. Methods and Equations for Estimating Aboveground Volume, Biomass, and Carbon for Trees in the U.S. Forest Inventory, 2010; U.S. Department of Agriculture, Forest Service, Northern Research Station: Amherst, MA, USA, 2011; p. 34.

120. Smith, J.E.; Heath, L.S.; Nichols, M.C. US Forest Carbon Calculation Tool: Forest-Land Carbon Stocks and Net Annual Stock Change; U.S. Department of Agriculture, Forest Service, Northern Research Station: Amherst, MA, USA, 2007.

121. Heath, L.S.; Nichols, M.C.; Smith, J.E.; Mills, J.R. FORCARB2: An Updated Version of the US Forest Carbon Budget Model; Northern Research Station: Newtown, PA, USA, 2010. 
122. Weifeng, W.; Changhui, P.; Larocque, G. Chapter 9: Modeling forest carbon budgets toward ecological forest management: Challenges and future directions. In Ecological Forest Management Handbook; Applied Ecology and Environmental Management; CRC Press: Boca Raton, FL, USA, 2015; pp. 267-279, ISBN 978-1-4822-4785-5.

123. Harmon, M.E.; Marks, B. Effects of silvicultural practices on carbon stores in Douglas-fir western hemlock forests in the Pacific Northwest, USA: Results from a simulation model. Can. J. For. Res. 2002, 32, 863-877. [CrossRef]

124. Houghton, R.A.; Hobbie, J.E.; Melillo, J.M.; Moore, B.; Peterson, B.J.; Shaver, G.R.; Woodwell, G.M. Changes in the carbon content of terrestrial biota and soils between 1860 and 1980: A net release of CO" 2 to the atmosphere. Ecol. Monogr. 1983, 53, 235-262. [CrossRef]

125. Mitchell, S.R.; Harmon, M.E.; O'Connell, K.E.B. Carbon debt and carbon sequestration parity in forest bioenergy production. GCB Bioenergy 2012, 4, 818-827. [CrossRef]

126. Peltzer, D.A.; Allen, R.B.; Lovett, G.M.; Whitehead, D.; Wardle, D.A. Effects of biological invasions on forest carbon sequestration. Glob. Chang. Biol. 2010, 16, 732-746. [CrossRef]

127. Redmond, R.L.; Hart, M.M.; Winne, J.C.; Williams, W.A.; Thornton, P.C.; Ma, Z.; Tobalske, C.M.; Thornton, M.M.; McLaughlin, K.P.; Tady, T.P.; et al. The Montana Gap Analysis Project: Final Report; Montana Cooperative Wildlife Research Unit, University of Montana: Missoula, MT, USA, 1998.

128. Squires, J.R.; Decesare, N.J.; Kolbe, J.A.; Ruggiero, L.F. Seasonal resource selection of Canada lynx in managed forests of the northern Rocky Mountains. J. Wildl. Manag. 2010, 74, 1648-1660. [CrossRef]

129. Smucker, K.M.; Hutto, R.L.; Steele, B.M. Changes in bird abundance after wildfire: Importance of fire severity and time since fire. Ecol. Appl. 2005, 15, 1535-1549. [CrossRef]

130. Levin, S.A. The problem of pattern and scale in ecology: The Robert H. MacArthur award lecture. Ecology 1992, 73, 1943-1967. [CrossRef]

131. Holling, C.S. Cross-scale morphology, geometry, and dynamics of ecosystems. In Ecosystem Management; Springer: Berlin, Germany, 1996; pp. 351-423.

132. Allen, C.R.; Angeler, D.G.; Garmestani, A.S.; Gunderson, L.H.; Holling, C.S. Panarchy: Theory and application. Ecosystems 2014, 17, 578-589. [CrossRef]

133. Moorcroft, P.R.; Hurtt, G.C.; Pacala, S.W. A method for scaling vegetation dynamics: The ecosystem demography model (ED). Ecol. Monogr. 2001, 71, 557-586. [CrossRef]

134. Rastetter, E.B.; Aber, J.D.; Peters, D.P.C.; Ojima, D.S.; Burke, I.C. Using mechanistic models to scale ecological processes across space and time. BioScience 2003, 53, 68-76. [CrossRef]

135. Urban, D.L. Modeling ecological processes across scales. Ecology 2005, 86, 1996-2006. [CrossRef]

136. He, H.S. Forest landscape models: Definitions, characterization, and classification. For. Ecol. Manag. 2008, 254, 484-498. [CrossRef]

137. Böhringer, C.; Jochem, P.E. Measuring the immeasurable-A survey of sustainability indices. Ecol. Econ. 2007, 63, 1-8. [CrossRef]

138. Fancy, S.G.; Gross, J.E.; Carter, S.L. Monitoring the condition of natural resources in US national parks. Environ. Monit. Assess. 2009, 151, 161-174. [CrossRef] [PubMed]

139. U.S. Department of Agriculture (USDA). Watershed Condition Framework: A Framework for Assessing and Tracking Changes to Watershed Condition; USDA: Washington, DC, USA, 2011.

140. Palmer, M.A. Socioenvironmental sustainability and actionable science. BioScience 2012, 62, 5-6. [CrossRef]

141. Wiek, A.; Ness, B.; Schweizer-Ries, P.; Brand, F.S.; Farioli, F. From complex systems analysis to transformational change: A comparative appraisal of sustainability science projects. Sustain. Sci. 2012, 7, 5-24. [CrossRef]

142. Miller, T.R.; Wiek, A.; Sarewitz, D.; Robinson, J.; Olsson, L.; Kriebel, D.; Loorbach, D. The future of sustainability science: A solutions-oriented research agenda. Sustain. Sci. 2014, 9, 239-246. [CrossRef]

143. Cash, D.; Adger, W.N.; Berkes, F.; Garden, P.; Lebel, L.; Olsson, P.; Pritchard, L.; Young, O. Scale and cross-scale dynamics: Governance and information in a multilevel world. Ecol. Soc. 2006, 11. [CrossRef]

144. Fischer, J.; Dyball, R.; Fazey, I.; Gross, C.; Dovers, S.; Ehrlich, P.R.; Brulle, R.J.; Christensen, C.; Borden, R.J. Human behavior and sustainability. Front. Ecol. Environ. 2012, 10, 153-160. [CrossRef]

145. Tallis, H.; Kareiva, P.; Marvier, M.; Chang, A. An ecosystem services framework to support both practical conservation and economic development. Proc. Natl. Acad. Sci. USA 2008, 105, 9457-9464. [CrossRef] [PubMed] 
146. De Groot, R. Function-analysis and valuation as a tool to assess land use conflicts in planning for sustainable, multi-functional landscapes. Landsc. Urban Plan. 2006, 75, 175-186. [CrossRef]

147. Duncker, P.S.; Raulund-Rasmussen, K.; Gundersen, P.; Katzensteiner, K.; De Jong, J.; Ravn, H.P.; Smith, M.; Eckmüllner, O.; Spiecker, H. How forest management affects ecosystem services, including timber production and economic return: Synergies and trade-offs. Ecol. Soc. 2012, 17, 50. [CrossRef]

148. Hansson, L.-A.; Bronmark, C.; Anders Nilsson, P.; Abjornsson, K. Conflicting demands on wetland ecosystem services: Nutrient retention, biodiversity or both? Freshw. Biol. 2005, 50, 705-714. [CrossRef]

149. Jessop, J.; Spyreas, G.; Pociask, G.E.; Benson, T.J.; Ward, M.P.; Kent, A.D.; Matthews, J.W. Tradeoffs among ecosystem services in restored wetlands. Biol. Conserv. 2015, 191, 341-348. [CrossRef]

150. DeCesare, N.J.; Pletscher, D.H. Movements, Connectivity, and resource selection of Rocky Mountain bighorn sheep. J. Mammal. 2006, 87, 531-538. [CrossRef]

151. Naudts, K.; Chen, Y.; McGrath, M.J.; Ryder, J.; Valade, A.; Otto, J.; Luyssaert, S. Europe's forest management did not mitigate climate warming. Science 2016, 351, 597-600. [CrossRef] [PubMed]

152. Sanderson, M.; Santini, M.; Valentini, R.; Pope, E. Relationships between Forests and Weather; EC Directorate General of the Environment; UK Met Office: Devon, UK, 2012.

153. Holling, C.S. Understanding the complexity of economic, ecological, and social systems. Ecosystems 2001, 4, 390-405. [CrossRef]

154. Peters, D.P.C.; Bestelmeyer, B.T.; Turner, M.G. Cross-scale interactions and changing pattern-process relationships: Consequences for system dynamics. Ecosystems 2007, 10, 790-796. [CrossRef]

155. Scholes, R.J. Taking the mumbo out of the jumbo: Progress towards a robust basis for ecological scaling. Ecosystems 2017, 20, 4-13. [CrossRef]

156. Von Uexküll, J.; Mackinnon, D.L. Theoretical Biology; Paul, K., Ed.; Trench, Trubner \& Co. Ltd.: London, UK; Harcourt, Brace \& Company: San Diego, CA, USA, 1926.

157. Farina, A. The landscape as a semiotic interface between organisms and resources. Biosemiotics 2008, 1, 75. [CrossRef]

158. Farina, A.; Santolini, R.; Pagliaro, G.; Scozzafava, S. Schipani eco-semiotics: A new field of competence for ecology to overcome the frontier between environmental complexity and human culture in the Mediterranean. Isr. J. Plant Sci. 2005, 53, 167-175. [CrossRef]

159. Kull, K. Ecosystems are made of semiosic bonds: Consortia, umwelten, biophony and Ecological Codes. Biosemiotics 2010, 3, 347-357. [CrossRef]

160. Ludwig, D.; Jones, D.D.; Holling, C.S. Qualitative analysis of insect outbreak systems: The spruce budworm and forest. J. Anim. Ecol. 1978, 47,315-332. [CrossRef]

161. Sundstrom, S.M.; Allen, C.R.; Barichievy, C. Species, Functional groups, and thresholds in ecological resilience. Conserv. Biol. 2012, 26, 305-314. [CrossRef] [PubMed]

162. Breshears, D.D.; Myers, O.B.; Meyer, C.W.; Barnes, F.J.; Zou, C.B.; Allen, C.D.; McDowell, N.G.; Pockman, W.T. Tree die-off in response to global change-type drought: Mortality insights from a decade of plant water potential measurements. Front. Ecol. Environ. 2009, 7, 185-189. [CrossRef]

163. Woodall, C.W.; Zhu, K.; Westfall, J.A.; Oswalt, C.M.; D'Amato, A.W.; Walters, B.F.; Lintz, H.E. Assessing the stability of tree ranges and influence of disturbance in eastern US forests. For. Ecol. Manag. 2013, 291, 172-180. [CrossRef]

164. Beckage, B.; Osborne, B.; Gavin, D.G.; Pucko, C.; Siccama, T.; Perkins, T. A rapid upward shift of a forest ecotone during 40 years of warming in the Green Mountains of Vermont. Proc. Natl. Acad. Sci. USA 2008, 105, 4197-4202. [CrossRef] [PubMed]

165. Adams, M.A. Mega-fires, tipping points and ecosystem services: Managing forests and woodlands in an uncertain future. For. Ecol. Manag. 2013, 294, 250-261. [CrossRef]

166. Mitchell, R.J.; Liu, Y.; O’Brien, J.J.; Elliott, K.J.; Starr, G.; Miniat, C.F.; Hiers, J.K. Future climate and fire interactions in the southeastern region of the United States. For. Ecol. Manag. 2014, 327, 316-326. [CrossRef]

167. Anderegg, W.R.; Kane, J.M.; Anderegg, L.D. Consequences of widespread tree mortality triggered by drought and temperature stress. Nat. Clim. Chang. 2013, 3, 30-36. [CrossRef]

168. Chmura, D.J.; Anderson, P.D.; Howe, G.T.; Harrington, C.A.; Halofsky, J.E.; Peterson, D.L.; Shaw, D.C.; Clair, J.B.S. Forest responses to climate change in the northwestern United States: Ecophysiological foundations for adaptive management. For. Ecol. Manag. 2011, 261, 1121-1142. [CrossRef] 
169. Duran, J.; Morse, J.L.; Groffman, P.M.; Campbell, J.L.; Christenson, L.M.; Driscoll, C.T.; Fahey, T.J.; Fisk, M.C.; Mitchell, M.J.; Templer, P.H. Winter climate change affects growing-season soil microbial biomass and activity in northern hardwood forests. Glob. Chang. Biol. 2014, 20, 3568-3577. [CrossRef] [PubMed]

170. Mitchell, S.J. Wind as a natural disturbance agent in forests: A synthesis. Forestry 2012, 86, 147-157. [CrossRef]

171. Lackey, R.T. Seven pillars of ecosystem management. Landsc. Urban Plan. 1998, 40, 1-3. [CrossRef]

172. Landres, P.B.; Morgan, P.; Swanson, F.J. Overview of the use of natural variability concepts in managing ecological systems. Ecol. Appl. 1999, 9, 1179-1188.

173. Hall, C.; Lindenberger, D.; KüMmel, R.; Kroeger, T.; Eichhorn, W. The need to reintegrate the natural sciences with economics. BioScience 2001, 51, 663. [CrossRef]

174. Lindenmayer, D.B.; Likens, G.E. The science and application of ecological monitoring. Biol. Conserv. 2010, 143, 1317-1328. [CrossRef]

175. Wiens, J.A. Spatial scaling in ecology. Funct. Ecol. 1989, 3, 385-397. [CrossRef]

176. Wood, D.J.A.; Carter, S.K.; Litschert, S.; Carr, N. Including broad-scale indicators in multiscale natural resource monitoring and assessment programs in the bureau of land management. In Multiscale Guidance and Tools for Implementing a Landscape Approach to Resource Management in the Bureau of Land Management; Bureau of Land Management: Washington, DC, USA, 2017; pp. 19-38.

177. Hilsenhoff, W.L. Rapid Field Assessment of organic pollution with a family-level biotic index. J. N. Am. Benthol. Soc. 1988, 7, 65-68. [CrossRef]

178. DeFries, R.; Nagendra, H. Ecosystem management as a wicked problem. Science 2017, 356, $265-270$. [CrossRef] [PubMed]

179. Imperial, M.T.; Ospina, S.; Johnston, E.; O’Leary, R.; Thomsen, J.; Williams, P.; Johnson, S. Understanding leadership in a world of shared problems: Advancing network governance in large landscape conservation. Front. Ecol. Environ. 2016, 14, 126-134. [CrossRef]

180. Costanza, R.; Kubiszewski, I.; Ervin, D.E.; Bluffstone, R.; Brown, D.; Chang, H.; Dujon, V.; Granek, E.F.; Polasky, S.; Shandas, V.; et al. Valuing ecological systems and services. F1000 Biol. Rep. 2011, 3, 14. [CrossRef] [PubMed]

181. De Groot, R.S.; Wilson, M.A.; Boumans, R.M.J. A typology for the classification, description and valuation of ecosystem functions, goods and services. Ecol. Econ. 2002, 41, 393-408. [CrossRef]

182. Stoy, P.C.; Ahmed, S.; Jarchow, M.; Rashford, B.; Swanson, D.; Albeke, S.; Bromley, G.; Brookshire, E.N.J.; Dixon, M.D.; Haggerty, J.; et al. Opportunities and trade-offs among BECCS and the food, water, energy, biodiversity, and social systems nexus at regional scales. BioScience 2018, 68, 100-111. [CrossRef]

183. Brown, T.C.; Bergstrp, J.C.; Loomis, J.B. Defining, valuing, and providing ecosystem goods and services. Nat. Resour. J. 2007, 47, 329-376.

184. Stern, N.H. The Economics of Climate Change: The Stern Review; Cambridge University Press: Cambridge, UK, 2007; ISBN 978-0-521-70080-1.

185. Boumans, R.; Costanza, R.; Farley, J.; Wilson, M.A.; Portela, R.; Rotmans, J.; Villa, F.; Grasso, M. Modeling the dynamics of the integrated earth system and the value of global ecosystem services using the GUMBO model. Ecol. Econ. 2002, 41, 529-560. [CrossRef]

186. U.S. Environmental Protection Agency (USEPA). Assessing the Benefits of Wetland Restoration: A Rapid Benefit Indicators Approach for Decision Makers; National Health and Environmental Effects Research Laboratory: Louisville, KY, USA, 2016; p. 111.

187. InVEST (Natural Capital Project). Available online: https://www.naturalcapitalproject.org/invest/ (accessed on 2 February 2018).

(C) 2018 by the authors. Licensee MDPI, Basel, Switzerland. This article is an open access article distributed under the terms and conditions of the Creative Commons Attribution (CC BY) license (http://creativecommons.org/licenses/by/4.0/). 